\title{
Pengendalian Mutu Produk Air Minum Kemasan Menggunakan New Seven Tools (Studi Kasus di PT. DEA)
}

\author{
${ }^{1}$ Yuza Zakariya, ${ }^{2}$ Muhammad Fuad Fauzul Mu'tamar * ${ }^{3}$ Khoirul Hidayat \\ 1,2,3 Teknologi Industri Pertanian, Universitas Trunojoyo Madura \\ 1140331100071@student.trunojoyo.ac.id, ${ }^{2}$ mfuadfm@gmail.com, ${ }^{3}$ irul_ie@yahoo.co.id
}

DOI: https://doi.org/10.21107/rekayasa.v13i2.5453

\section{Analysis of Quality Control of Drinking Water Products in Cup Using New Seven Tools Method (Case Study in PT. DEA)}

\section{ABSTRACT}

Quality control is an activity of monitoring and evaluation as well as following up on a process so that the specified quality requirements can be achieved. Improving the quality of an industry must go through a process of quality control of its production. The purpose of this study is to obtain a process of improving quality through the application of new seven tools. The new seven tools method includes several stages, namely affinity diagrams, tree diagrams, process decision program charts (PDPC) and activity network diagrams. The results showed that there were three types of product defects, namely incomplete contents, tilted lid cups and less tight cup lid strength with the greatest level of defect in the tilted lid cup. The results of the analysis found there are three factors causing the emergence of defects in drinking water products in $240 \mathrm{ml}$ cup packaging, namely machinery and equipment, human resources (HR) and methods. Some proposed alternative improvements are to improve the condition of machinery and equipment, increase human resources (HR) and use appropriate methods in production. Based on the network diagram, the process of product defect control at PT. DEA requires an average time of 27 days.

Keywords: Quality control, new seven tools, product defects

\section{ABSTRAK}

Pengendalian mutu merupakan kegiatan pemantauan dan evaluasi serta menindaklanjuti suatu proses agar persyaratan mutu yang telah ditetapkan dapat tercapai. Peningkatan kualitas mutu suatu industry harus melalui proses pengendalian mutu terhadap produksinya. Tujuan dari penelitian ini adalah mendapatkan proses perbaikan kualitas mutu melalui penerapan new seven tools. Metode new seven tools meliputi beberapa tahapan yaitu diagram afinitas, diagram pohon, process decision program chart (PDPC) dan activity network diagram. Hasil penelitian menunjukkan terdapat tiga macam cacat produk yaitu isi tidak penuh, lid cup miring dan kekuatan lid cup kurang rapat dengan tingkat kecacatan terbesar pada lid cup miring. Hasil analisis didapatkan ada tiga faktor penyebab timbulnya cacat produk air minum dalam kemasan cup 240ml yaitu mesin dan peralatan, sumber daya manusia (SDM) dan metode. Beberapa usulan alternatif perbaikan yaitu melakukan perbaikan kondisi mesin dan peralatan, meningkatkan sumber daya manusia (SDM) dan penggunaan metode sesuai dalam produksi. Berdasarkan diagram jaringan kerja, proses pengendalian kecacatan produk di PT. DEA membutuhkan waktu rata rata selama 27 hari. Kata Kunci: Pengendalian mutu, new seven tools, kecacatan produk.

\section{PENDAHULUAN}

Perusahaan air minum dalam kemasan khususnya di Indonesia tergolong cukup banyak. Tercatat menurut (Statistik, 2014) pada tahun 2013 terdapat 348 perusahaan yang bergerak dalam bidang produksi air minum dalam kemasan. Hal tersebut menunjukkan bahwa potensi perusahaan dalam bidang air minum dalam kemasan cukup menjanjikan untuk berkembang di Indonesia, mengingat populasi masyarakat Indonesia sendiri yang lebih suka dengan sesuatu yang sifatnya praktis. Faktor yang dapat mempengaruhi kualitas air minum dalam kemasan diantaranya adalah air baku, jenis peralatan yang digunakan dalam produksi, pemeliharaan peralatan produksi, penanganan pengolahan dan pendistribusian air (Mirza, 2014).

Pengendalian mutu merupakan kegiatan pemantauan, evaluasi dan upaya tindak lanjut dalam mencapai persyaratan mutu yang ditetapkan dalam produksinya (Riyanto, 2014). Pengendalian mutu

\section{Article History:}

Received: June, 23 ${ }^{\text {th }}$ 2019; Accepted: May, $10^{\text {th }} 2020$

ISSN: 2502-5325 (Online) Terakreditasi Peringkat 3 oleh Kementerian Riset, Teknologi dan Pendidikan Tinggi (ARJUNA) berdasarkan Keputusan Direktur Jenderal Penguatan Riset dan Pengembangan No: 23/E/KPT/2019 tanggal 8 Agustus 2019 perusahaan dilakukan oleh bagian pengawas mutu terpisah dari bagian proses produksi. Jika perusahaan mampu menekan tingkat kecacatan produk, maka perusahaan kemungkinan mendapatkan keuntungan akan jauh lebih besar (Suwandi, 2016). New seven tools merupakan alat pengendalian persediaan yang melakukan pendekatan dengan cara pendekatan desain, yaitu pendekatan bersifat komprehensif dalam memecahkan masalah yang menaruh perhatian besar pada setiap aspek detail dan melibatkan setiap orang yang memiliki latar belakang berbeda. Tujuh alat yang digunakan dalam metode ini yaitu Digram Afinitas, Relation Diagram (Diagram Hubungan), Digaram Pohon, Diagram Matriks Analisis Data, Process Decision Program Chart (PDPC), Prioritization Grid, Activity Network Diagram (Arif, 2016)

PT DEA merupakan salah satu industri air minum dalam kemasan cup 240ml yang terletak di kabupaten Gresik. Suatu produk yang diproduksi dan dihasilkan oleh PT DEA sudah terkenal di kabupaten Gresik. Produksi air minum dalam kemasan

\section{Cite this as:}

Zakariya, Y. Mu'tamar, M.F.F. \& Hidayat, K. (2020). Pengendalian Mutu Produk Air Minum Kemasan Menggunakan New Seven Tools (Studi Kasus di PT. DEA). Rekayasa, 13(2), 97-102. doi: https://doi.org/10.21107/rekayasa.v13i2.5453 
cup 240ml pada tahun 2017 dilihat terjadi fluktuasi dalam setiap bulannya. Hal tersebut perlu diidentifikasikan penyebab terjadinya tinggi rendahnya produksi, salah satu penyebabnya adalah cacat produk. Kemungkinan penyebab cacat produk yang terjadi pada saat produksi dapat merugikan perusahaan baik dari segi materi maupun non materi (Wibowo \& Emy, 2014). Terdapat jenis kecacatan produk air minum dalam kemasan cup 240 $\mathrm{ml}$ yaitu isi yang tidak penuh, Lid Cup miring dan kekuatan Lid Cup pada kemasan. Sehingga dalam pengendalian mutu produk air minum dalam kemasan akan difokuskan ke hal tersebut yang harapannya dapat menghasilkan zero defect atau tidak adanya cacat produk.

\section{METODE PENELITIAN}

Objek penelitian ini adalah PT. DEA. Ada beberapa variable analisis untuk mendukung penggunaan metode New Seven Tools, yaitu sebagai berikut:

\section{Diagram Afinitas}

Digram Afinitas digunakan untuk mengorganisir dan mengumpulkan fakta, opini dan ide yang bertujuan untuk memperoleh suatu hasil dalam bentuk grafis (Sugian, 2006).

Langkah-langkah dalam pembuatan diagram afinitas:

a. Memilih topik yang akan dibahas.

b. Melakukan interview / wawancara dengan perusahaan mengenai faktor-faktor yang dapat menyebabkan kecacatan produk.

c. Mengumpulkan pendapat atau gagasan dari hasil interview yang memiliki kesamaan atau keterkaitan erat dalam satu kelompok.

d. Membiarkan pendapat atau gagasan yang tidak memiliki kesamaan atau keterkaitan erat dengan kelompok manapun berada di luar kelompok.

e. Memberikan kategori (nama) atas setiap kelompok, dan mengklasifikasi gagasan setiap kategori dalam hubungan induk cabang.

f. Membentuk diagram afinitas.

\section{Diagram Pohon}

Diagram Pohon digunakan untuk menunjukkan interrelasi antara sasaran dan ukuran, atau dalam kata lain digunakan untuk mengidentifikasi tahapan yang diperlukan dalam sebuah pemecahan masalah. Tahap penyelesaian masalah dilakukan dari level paling bawah secara bertahap kemudian menuju ke level paling atas atau masalah pokoknya (Arif, 2016).

Langkah-langkah dalam pembuatan diagram pohon:

a. Mengidentifikasi masalah prioritas yang perlu diselesaikan di awal.

b. Melakukan interview dan diskusi dengan pihak perusahaan mengenai berbagai alternatif yang dapat dilakukan dalam mengurangi kecacatan produk.

c. Mengidentifikasi cara-cara utama yang diperlukan untuk mencapai masalah prioritas yang perlu diselesaikan.

d. Untuk masing-masing alat utama, mengidentifikasi cara-cara sekunder yang diperlukan untuk mencapai sarana tersebut. Mengaturnya dalam kotak tingkat berikutnya.

e. Mengidentifikasi cara tersier yang diperlukan untuk mencapai masing-masing sarana sekunder dan menempatkan masalah dalam urutan yang tepat di kotak tingkat berikutya.

f. Melanjutkan proses selama masih memungkinkan.

g. Menelusuri ulang untuk memastikan kesesuaian antar tingkat

\section{Process Decision Program Chart (PDPC)}

Process Decision Program Chart (PDPC) merupakan alat yang berguna untuk membantu menentukan proses yang digunakan untuk mendapatkan hasil yang diinginkan dengan cara mengevaluasi peristiwa dan variasi hasil yang mungkin terjadi (Arif, 2016)

Langkah-langkah dalam pembuatan PDPC:

a. Mentukan titik awal dan kondisi akhir permasalahan yang ingin diselesaikan.

b. Menyiapkan rencana kegiatan untuk mencapai tujuan yang diharapkan.

c. Melakukan interview dan diskusi dengan pihak perusahaan untuk mengidentifikasi faktor-faktor hambatan dalam melaksanakan rencana kerja.

d. Mengidentifikasi solusi yang tepat untuk mengatasi hambatan yang terjadi.

e. Mengidentifikasi hambatan yang mungkin terjadi pada saat melakukan solusi dan mencari solusi untuk melawan hambatan tersebut sampai mencapai tujuan akhir yang diinginkan.

f. Melakukan update jika situasi berubah, jika memang tidak ada/tidak bisa disolusikan: berhenti.

g. Pada akhir proses memberikan simbol "O" jika upaya penanggulangan dapat dilakukan dan simbol " $X$ " jika upaya penanggulangan sulit dilakukan.

\section{Activity Network Diagram}

Activity Network Diagram merupakan diagram yang menggambarkan hubungan diantara berbagai kegiatan serta mengidentifikasi kegiatan kritis dan lintasan kritis (Herdjanto, 2007).

Langkah-langkah dalam pembuatan activity network diagram:

a. Mengilustrasikan urutan operasi mulai dari paling kiri.

b. Menentukan langkah-langkah yang dilaku- 
kan secara seri dan yang dapat dijalankan secara paralel.

c. Menuliskan nomer operasi dan nomer persimpangan.

d. Mengatur kegiatan pada operasi dalam urutan yang tepat.

e. Menuliskan deskripsi kegiatan di atas garis dan menentukan waktu yang dibutuhkan untuk menyelesaikan setiap kegiatan dan menulisnya di bawah atau disebelah kanan baris.

f. Menggambarkan garis panah dengan garis lurus berarti harus berurutan sedangkan putus-putus berhubungan tapi masih bisa ditunggu (tidak ada waktu).

g. Menggambarkan jalur kritis (tidak bisa ditunda) dengan garis panah yang lebih tebal.

h. Membuat diagram jaringan kerja untuk mengetahui waktu yang dibutuhkan untuk melakukan perbaikan pada saat proses produksi berlangsung.

\section{HASIL DAN PEMBAHASAN}

Hasil identifikasi bagian produksi diketahui bahwa jenis kecacatan produk air minum dalam kemasan cup $240 \mathrm{ml}$ adalah isi yang tidak penuh, lid cup miring dan kekuatan lid cup pada kemasan. Dalam penelitian di PT. DEA. Peneliti akan menerapkan 4 alat kendali metode New Seven Tool, yaitu Digram Afinitas, Digaram Pohon, Process Decision Program Chart (PDPC), dan Activity Network Diagram adalah berikut:

\section{Diagram Afinitas}

Digram Afinitas digunakan untuk mengumpulkan dan mengorganisir fakta, opini dan ide yang bertujuan untuk memperoleh suatu hasil dalam bentuk grafis.
Berdasarkan Gambar $\mathbf{4 . 3}$ dapat diketahui bahwa terdapat tiga faktor penyebab terjadinya produk cacat berupa isi air yang tidak penuh, Lid Cup miring dan kekuatan Lid Cup yang kurang rapat di PT. DEA yaitu faktor peralatan dan mesin, faktor sumber daya manusia (SDM), dan faktor metode (Darsono, 2013).

\section{Diagram Pohon}

Diagram pohon digunakan untuk memecahkan suatu konsep atau aktivitas-aktivitas secara lebih terperinci ke dalam sub-sub komponen atau tingkat yang lebih rendah dan terperinci lagi. Berikut ini adalah diagram pohon terkait dengan berbagai alternatif yang dapat dilakukan untuk mengurangi kecacatan produk pada produksi air minum dalam kemasan di PT DEA dapat dilihat pada Gambar 4.4.

\section{Diagram Program Decision Process Chart (PDPC)}

Diagram Program Decision Process Chart (PDPC) digunakan untuk menganalisis hambatan-hambatan yang dapat terjadi ketika dilakukannya penerapan alternatif perbaikan di PT. DEA. Data mengenai hambatan yang dapat terjadi. Berikut adalah diagram yang menunjukkan hambatan yang mungkin saja bisa terjadi:

\section{Activity Network Diagram}

Setelah mengetahui penyebab terjadinya kecacatan produk pada proses produksi, kemudian menentukan rangkaian kegiatan yang dilakukan beserta durasi waktu yang dibutuhkan, menggunakan diagram jaringan kerja yang dapat dilihat pada gambar 4.6.

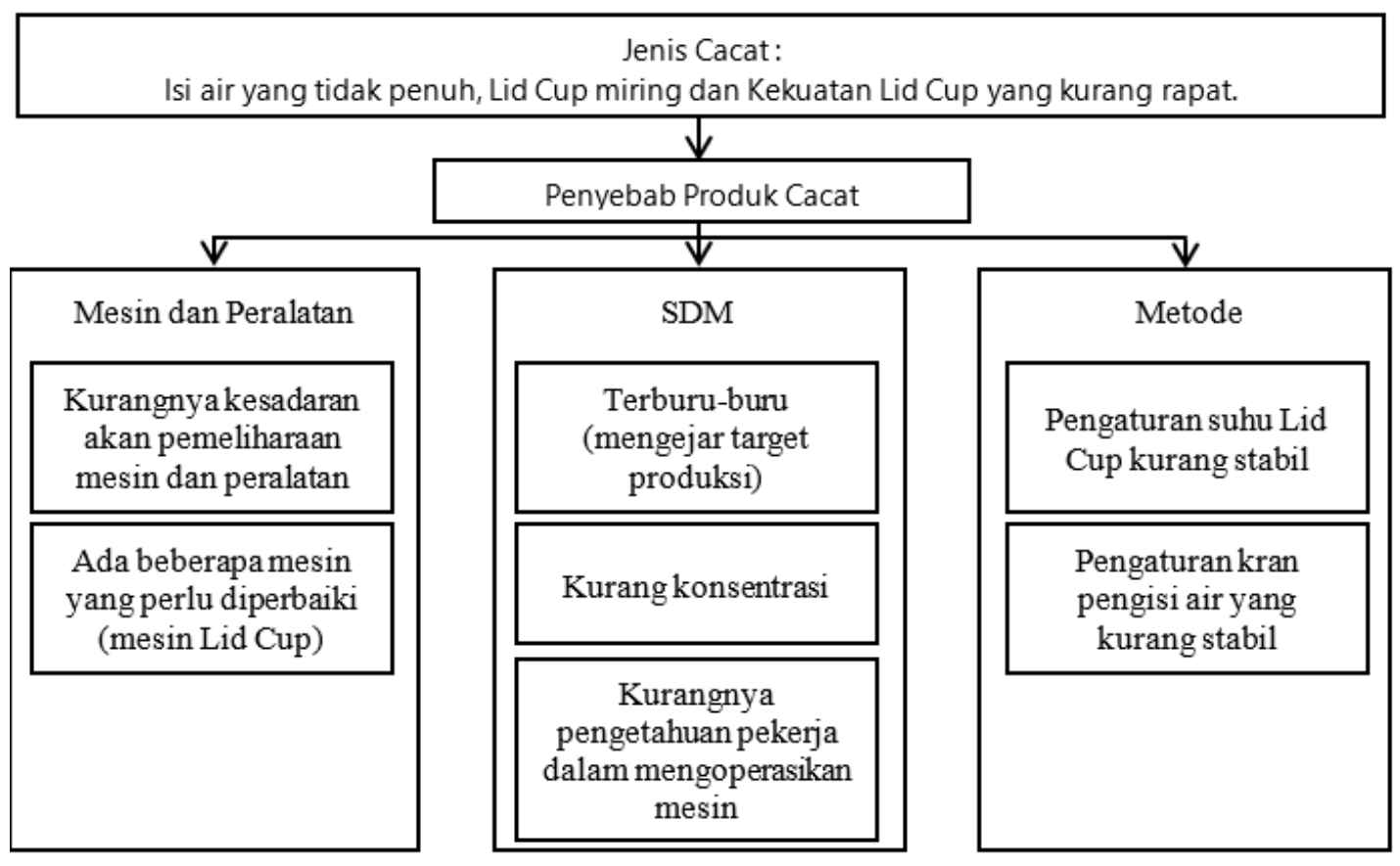

Gambar 4.3 Diagram Afinitas Penyebab Produk Cacat di PT. DEA 


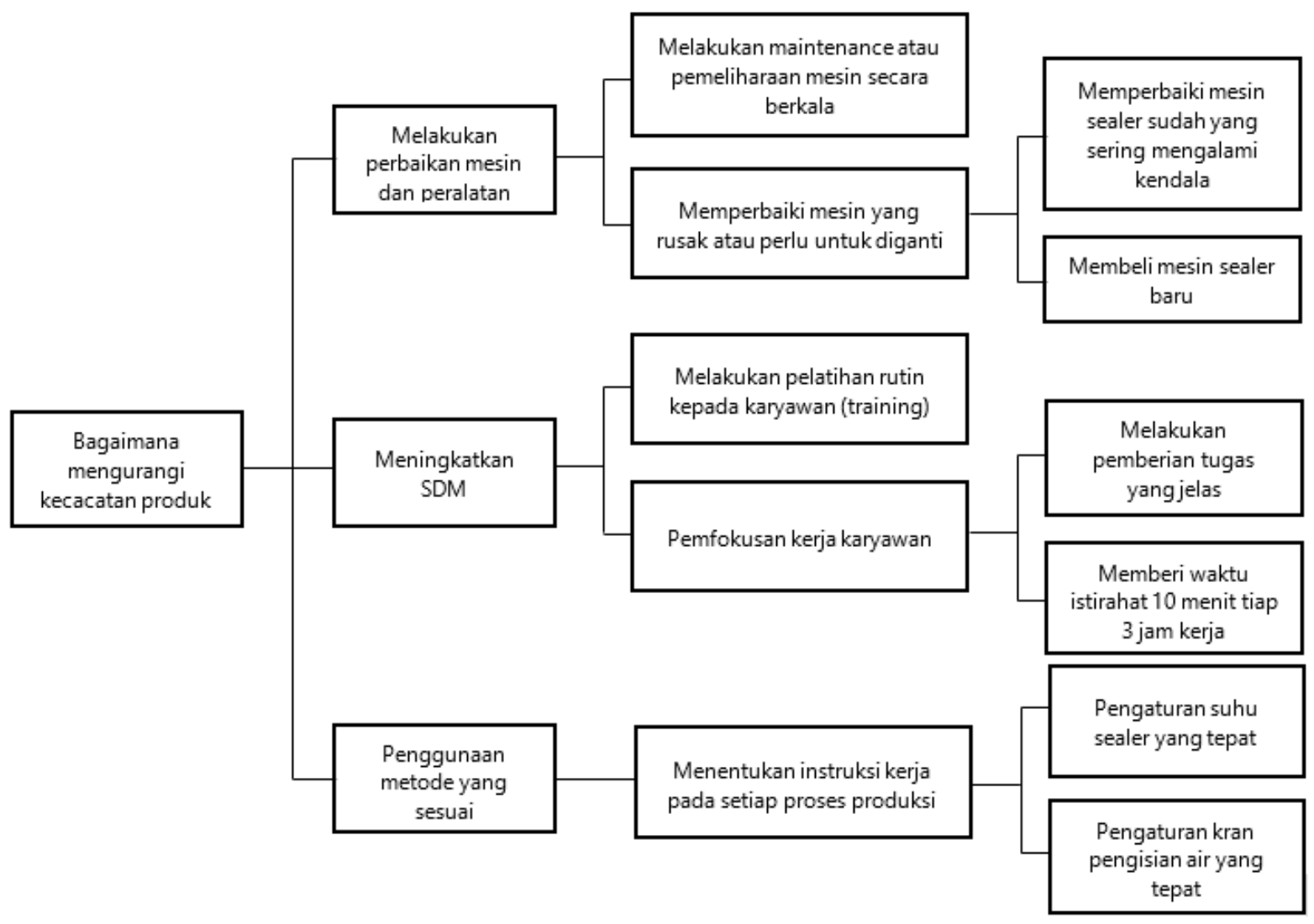

Gambar 4.4 Diagram Pohon Alternatif Perbaikan Proses Produksi Air Minum Dalam Kemasan di PT. DEA.

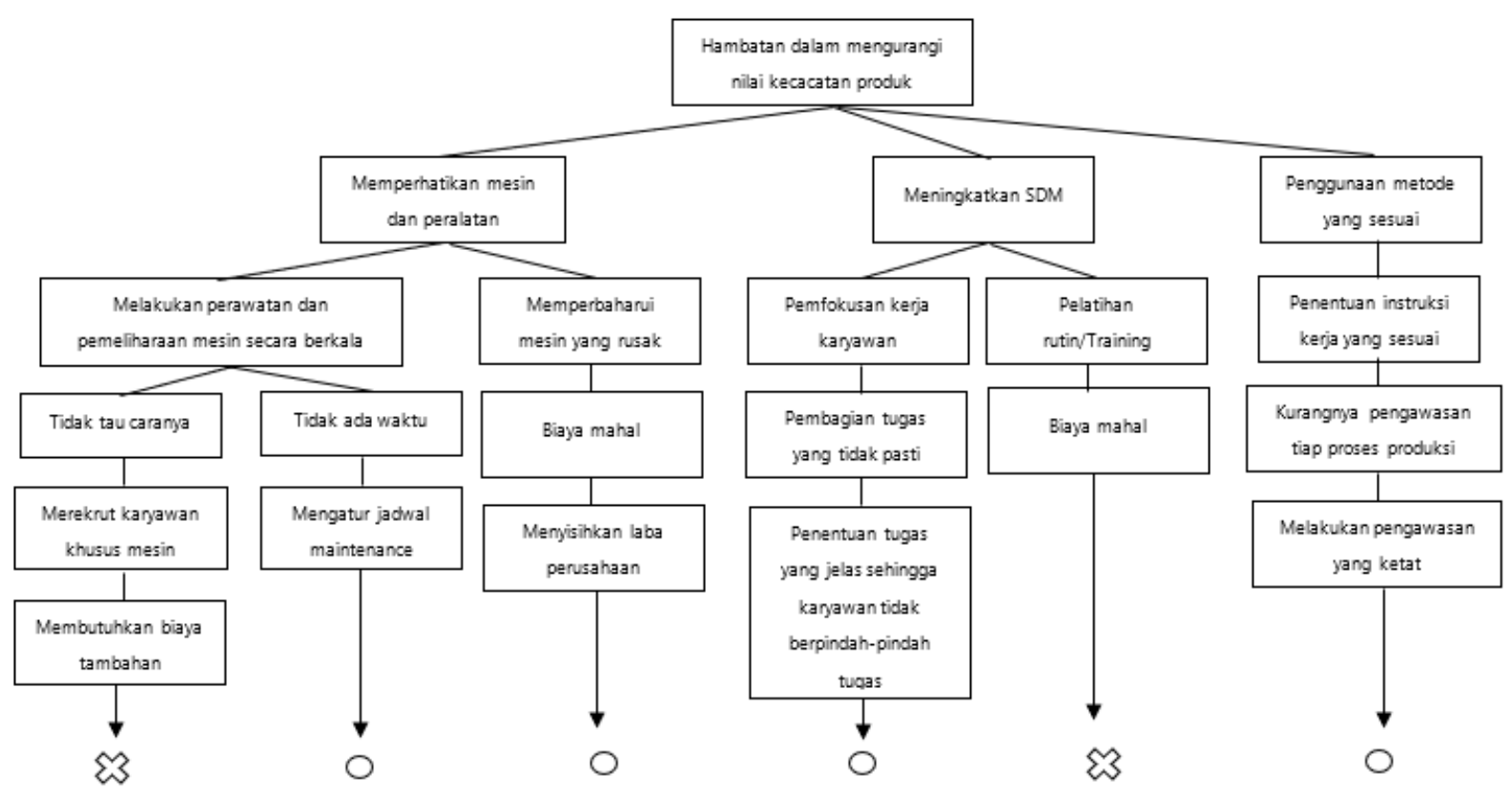

Ket : $\quad x$ : Tidak dapat diterapkan

o : Dapat diterapkan

Gambar 4.5 Diagram Program Decision Process Chart (PDPC) 


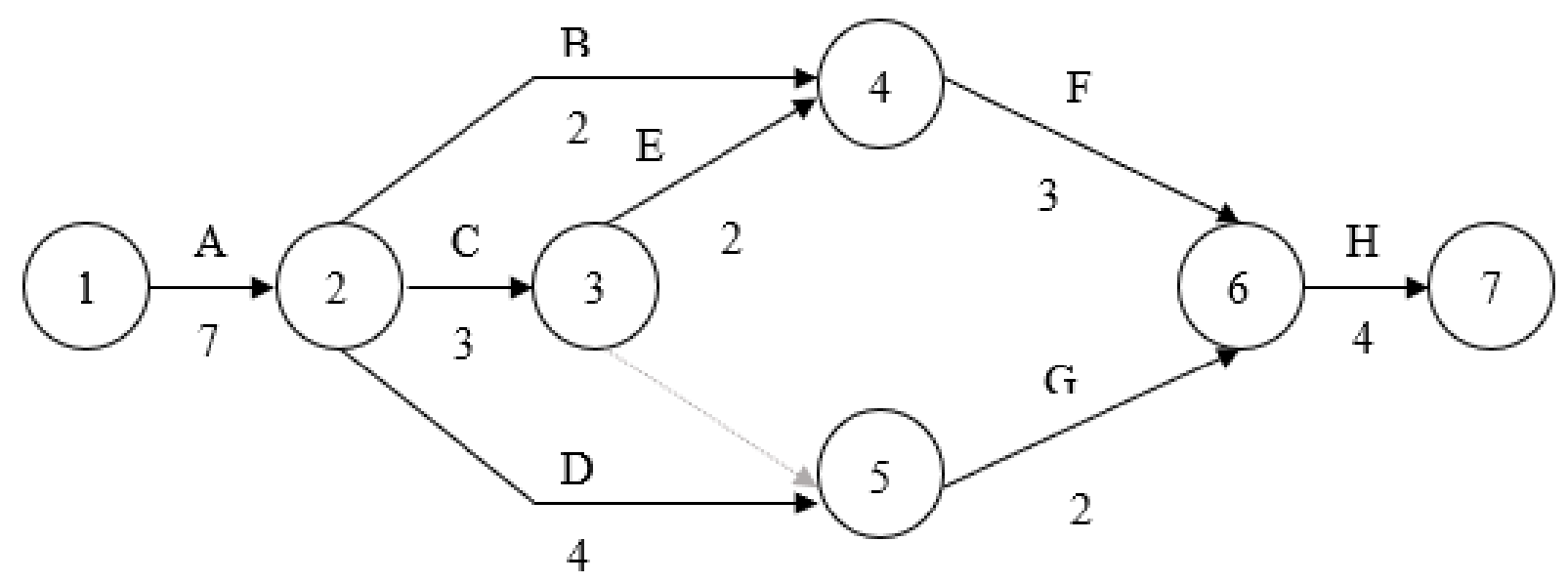

Gambar 4.6 Diagram Jaringan Kerja

Diagram jaringan kerja di atas memiliki rincian ke-

giatan dan waktu sesuatu pada tabel berikut :

Tabel 4.2 Rincian Kegiatan dan Waktu Proses Diagram Jaringan Kerja

\section{Lama Kegiatan (hari)}

\section{Kegiatan}

$\underset{\text { Pendahulu }}{\text { Kegiatan }} t_{o} \quad t_{m} \quad t_{p} \quad t=\frac{t_{o}+4 t_{m}+t_{p}}{6}$

\begin{tabular}{lccccc}
\hline A. Perancangan sistem & - & 5 & 7 & 9 & 7 \\
B. Pengecekan Mesin dan Peralatan & A & 1 & 2 & 3 & 2 \\
C. Mencari Penyebab Kecacatan & A & 3 & 3 & 3 & 3 \\
D. Pengecekan Kinerja Karyawan & A & 3 & 4 & 5 & 4 \\
E. Pengecekan Work Instruction & C & 2 & 2 & 2 & 2 \\
F. Melakukan Perbaikan Mesin dan Peralatan & B,E & 2 & 3 & 4 & 3 \\
G. Memberikan Pengarahan pada Karyawan & C,D & 1 & 2 & 3 & 2 \\
H. Finishing dan Start Up & F,G & 2 & 3 & 10 & 4 \\
\hline
\end{tabular}

Pada tabel di atas, dapat diketahui waktu rata-rata dalam menyelesaikan setiap proses perbaikan kerja di PT. DEA didapatkan menggunakan rumus

$\mathbf{t}=\frac{\boldsymbol{t}_{\boldsymbol{o}}+4 \boldsymbol{t}_{\boldsymbol{m}}+\boldsymbol{t}_{\boldsymbol{p}}}{\mathbf{6}}$ dimana :

$\mathrm{t}_{0}=$ estimasi waktu paling optimis (tercepat)

$t_{m}=$ estimasi waktu paling mungkin terjadi

$\mathrm{t}_{\mathrm{p}}^{\mathrm{m}}=$ estimasi waktu paling pesimis (terlama)

\section{KESIMPULAN DAN SARAN}

\section{Kesimpulan}

1. Proses produksi air minum dalam kemasan cup $240 \mathrm{ml}$ meliputi proses pengisian air ke dalam kemasan (filling), pemasangan lid cup (heatering), pemotongan kelebihan lid cup (cuttering), proses pembalikan cup, penyortiran, packing, pemasangan lakban dan penggudangan.

2. Terdapat tiga faktor penyebab kecacatan air minum dalam kemasan cup $240 \mathrm{ml}$ yaitu fak- tor mesin dan peralatan, faktor sumber daya manusia (SDM) dan faktor metode.

3. Hasil analisis menunjukkan bahwa usulan yang dapat diberikan terkait kecacatan produk yaitu melakukan perbaikan kondisi mesin dan peralatan, meningkatkan sumber daya manusia (SDM) dan penggunaan metode yang sesuai dalam produksi.

4. Berdasarkan diagram jaringan kerja bahwa proses atau tahapan untuk mengendalikan kecacatan produk di PT. DEA membutuhkan waktu rata rata selama 27 hari.

\section{Saran}

1. Perusahaan harus lebih memperhatikan mesin dan peralatan yang digunakan pada saat produksi serta memperbaharui mesin dan peralatan yang sudah tidak efisien lagi.

2. Sebelum produksi dilakukan, sebisa mungkin karyawan diberikan pengarahan agar dapat meminimalisir kesalahan pada saat produksi air minum dalam kemasan cup $240 \mathrm{ml}$. 
102 | Zakariya, Y. dkk. Pengendalian Mutu Produk Air Minum Kemasan...

\section{DAFTAR PUSTAKA}

Akhyar, Y. (2014). Manajemen Mutu Terpadu. Potensia: Jurnal Kependidikan Islam, 13(1), 1-20.

Arif, M. (2016). Bahan Ajar Rancangan Teknik Industri. Yogyakarta : CV. Budi Utama.

Darsono. (2013). Analisis Pengendalian Kualitas Produksi Dalam Upaya Mengendalikan Tingkat Kerusakan Produk. Jurnal Ekonomi-Manajemen-Akuntansi, 1(35), 1-17.

Deril, M., \& H, N. (2015). Uji parameter air minum dalam kemasan (AMDK) di Kota Surabaya. Jurnal IImiah Teknik Lingkungan, 6(1), 55-60.

Herdjanto, E. (2007). Manajemen Operasi. Jakarta : Grasindo.

Irawan, I., \& Sukantha. (2017). Pengendalian Proses Produksi dengan Metode Statistical Process Control dalam Upaya Minimasi Cacat Tissue Paper. Prosiding SNTI Dan SATELIT 2017 (Pp. D64-69), Malang: Jurusan Teknik Industri Universitas Brawij.

Jasasila, J. (2017). Peningkatan Mutu Pemeliharaan Mesin Pengaruhnya terhadap Proses Produksi pada PT. Aneka Bumi Pratama (ABP) di Kabupaten Batanghari. Jurnal Ilmiah Universitas Batanghari Jambi, 17(3), 96-102.

Ma'arif, S., \& Hendri, T. (2006). Manajemen operasi. Jakarta : Grasindo.

Mirza, M. N. (2014). Hygiene Sanitasi dan Jumlah Coliform Air Minum. Jurnal Kesehatan Masyarakat, 9(2), 167-173.
Perindustrian, M. (2011). Peraturan Menteri Perindustrian tentang Persyaratan Teknis Industri Air Minum dalam Kemasan nomor 96/M-IND/PER/12/2011.

Prihantoro, R. (2012). Konsep Pengendalian Mutu. Bandung: PT. Remaja Rosdakarya.

Riyanto. (2014). Validasi dan Verifikasi Metode Uji Sesuai dengan ISO/IEC 17025 Laboratorium Pengujian dan Kalibrasi. Yogyakarta: CV. Budi Utama.

Rodhi, F. A. (2013). Penentuan Jenis Maintenance yang Sesuai untuk Mesin Print Number Wheel PT. Barindo Anggun Industri. Jurnal Teknik Mesin Universitas Negeri Surabaya, 2(01), 96-104.

Statistik, B. P. (2014). Jumlah Perusahaan Industri Besar Sedang Menurut Sub Sektor, 20082013. Jakarta (ID): BPS.

Sugian, S. O. (2006). Kamus Manajemen Mutu. Jakarta : PT. Gramedia Pustaka Utama.

Suwandi, A. (2016). Peningkatan Kualitas untuk Meminimasi Cacat Produk Cat Plyurethane dengan Metode Taguchi. Jurnal Inovisi, 12(2), 55-71.

Wibowo, H., \& Emy, K. (2014). Analisis Kecacatan Produk Air Minum Dalam Kemasan (AMDK) Sebagai Upaya Perbaikan Kualitas Dengan Metode DMAIC. Jurnal Spektrum Industri, 12(2), 153-163.

Yana, S. (2015). Analisis Pengendalian Mutu Produk Roti pada Nusa Indah Bakery Kabupaten Aceh Besar. Industrial Engineering Journal (IEJ), 4(1), 17-23. 